\title{
PENGEMBANGAN SOFTWARE ANTI MISCHEM UNTUK MEREDUKSI MISKONSEPSI SISWA DENGAN STRATEGI CONCEPTUAL CHANGE TEXT PADA MATERI ASAM BASA KELAS XI SMA
}

\section{DEVELOPMENT OF SOFTWARE ANTI MISCHEM FOR REDUCING MISCONCEPTION OF STUDENTS WITH STRATEGIES CONCEPTUAL CHANGE TEXT IN ACID BASE OF CLASS XI SMA}

\author{
Fikri Sugiyantoro dan *Sukarmin \\ Jurusan Kimia FMIPA Universitas Negeri Surabaya
}

Email: sukarmin@unesa.ac.id

\begin{abstract}
Abstrak
Penelitian ini bertujuan untuk mengetahui kelayakan software anti mischem yang dikembangkan untuk mereduksi miskonsepsi pada materi asam basa kelas 11 dengan menggunakan stratgei conceptual chnage text. Kelayakan sebuah software dapat ditinjau tiga aspek, meliputi (1) Validitas dapat ditunjukan dengan validasi isi dan validasi konstruk, (2) Kepraktisan dapat ditunjukan dengan hasil angket respon siswa yang didukung dengan hasil obesrvasi aktivitas siswa, (3) Keefektifan dapat ditunjukan dengan hasil pergeseran konsepsi siswa dari miskonsepsi menjadi paham konsep. Metode yang digunakan dalam penelitian yaitu metode Research and Development (R\&D) yang dikembangkan oleh Sugiyono, dengan subjek 15 siswa SMAN 1 Krembung yang mempunyai persentase miskonsepsi tertinggi. Hasil penelitian yang dipeoleh menunjukan bahwa software dinyakatakan layak untuk mereduksi miskonsepsi siswa dalam materi asam basa dengan ditunjukannya perolehan validasi isi mendapatkan persentase rata-rata sebesar 84,63\% dan validasi konstruk memperoleh 82,22\%, kepraktisan dari hasil angket respon siswa mendapat rata-rata persentase sebesar 78,33\% dan obsevasi aktivitas siswa mendapat rata-rata persentase $85,83 \%$, serta keefektifan bisa ditunjukan dengan hasil pergeseran konsepsi siswa yang awalnya miskonsepsi menjadi paham konsep mendapatkan rata-rata persentase $85,52 \%$.
\end{abstract}

Kata kunci : Software Anti Mischem, Miskonsepsi, Conceptual Change Text, Asam Basa.

\begin{abstract}
The aims of this research are to know the feasibility of software anti mischem developed to reduce misconceptions material acid-base in $11^{\text {th }}$ grade by using conceptual change text strategy. The feasibility of software can be reviewed in three aspects, including (1) Validity can be reviewed from the content validation and construct validation, (2) Practicality can be demonstrated by the results of student response questionnaires that are supported by the results of student activity observation, (3) Effectiveness can be demonstrated by the results of students' conception shifts from misconception to conceptual understanding. The method used in the research is the Research and Development $(R \& D)$ method by Sugiyono, with the subject of 15 high school students 1 Krembung who has the highest percentage of misconceptions. The results obtained showed that the software was said to be feasible for reducing students misconception in acid-base material by demonstrating the content validation getting an average percentage of $84.76 \%$ and the construct validation of getting $82.22 \%$, the practicality of the results of the student questionnaire responses getting an average percentage of $78.33 \%$ and observing the activities of students getting an average the percentage of $85.83 \%$, as well as effectiveness can be demonstrated by results the conception shift of students who initially misconception into understanding the concept of getting an average percentage of $85.52 \%$.
\end{abstract}

Keywords: Software Anti-Mischem, Misconception, Conceptual Change Text, Acid-Base.

\section{PENDAHULUAN}

Suatu pembelajaran di indonesia tidak terlepas dari karangka dasar dan struktur kurikulum seperti halnya yang tercantum pada Kemendikbud No. 69 tahun 2013 mengenai kerangka dasar dan struktur kurikulum SMA/MA bahwa kurikulum 2013 telah menegaskan akan pemahaman konsep siswa dan penyempurnaan pola pikir yang berpusat pada siswa sehingga diharapkan siswa dapat memahami kesinambungan dan hirarki konsep. Pemahaman konsep secara utuh sangat berguna untuk siswa 
dan dapat diterapkan ke dalam keperluan yang lain [1].

Hasil studi dari literatur penelitian sebelumnya membuktikan bahwa besar miskonsepsi pada materi asam basa rata-rata sebesar $62,33 \%$ pada sekolahan SMAN 1 Krembung [2]. Sehingga pada KD.3.10 siswa kesusahan pada saat mempelajari konsep-konsep dasar yang ada dalam ilmu kimia. ilmu kimia termasuk kunci utama yang harus dipalajari, sebab pada materi yang ada didalamnya kebanyakan bersifat abstrak dan kompleks [3]. Hal ini siswa akan mengalami kesusahan pada saat mempelajari kimia dikarenakan konsep - konsep yang ada pada kimia saling berkaitan.

Pemahaman suatu konsep akan berdampak bagi konsep yang lain, sehingga dalam aktivitas pembelajaran akan menjadi sulit memahami suatu konsep dikarenakan siswa perlu menguasai setiap konsep dengan benar sebelum siswa mempelajari konsep lainnya. Hal ini mampu menimbulkan konsepsi yang berbeda dari setiap siswa. Salah satu konsepsi yang berbeda tersebut disebut dengan miskonsepsi [4].

Miskonsepsi ialah suatu konsepsi yang dipunyai siswa berbeda dari konsep ilmiah. Miskonsepsi adalah ketidaksesuaian dalam memahami sebuah konsep yang baru diterimanya sehingga berdampak pada proses hasil belajar siswa [5].

Banyak para peneliti yang melakukan penelitiannya untuk mengetahui miskonsepsi siswa dalam konsep kimia. Penelitan yang sudah dilakukan salah satu diantaranya meneliti miskonsepsi yang terjadi dalam materi asam basa. Asam basa merupakan materi yang memiliki karakteristik. karakteristik dari materi asam basa antara lain: bersifat kompleks, membandingkan perkembangan teori asam basa, kemampuan memahami reaksi disosiasi atau ionisasi. Pada materi asam basa tidak hanya mencakup teori dan proses saja, melainkan terdapat proses perhitungan yang mengandung pengolahan pecahan atau desimal[6] .

Berdasarkan hasil pra-penelitian pada semester gasal 2019/2020 yang didapatkan dari 3 sekolah di Sidoarjo yaitu: SMAN 1 Krembung, SMAN 1 Porong, dan MAN Sidoarjo menunjukan miskonsepsi dalam materi asam basa Arrhenius dengan analisis miskonsepsi terdapat 54,16\%, dalam materi asam basa Bronsted Lowry dengan analisis miskonsepsi terdapat $63,45 \%$, dalam materi asam basa Lewis dengan analisis miskonsepsi terdapat $54,7 \%$, sedangkan pada kekuatan asam siswa yang mengalami miskonsepsi terdapat 70,51\%.

Keadaan seperti ini tidak boleh terjadi begitu saja, sehingga diperlukannya buat menyembuhkan miskonsepsi. Terdapat satu cara mengidentifikasi miskonsepsi yang terjadi pada siswa yaitu dengan cara tes diagnostik empat tingkat (four-tier diagnostic test) yang merupakan pengembangan dari tes diagnostik tiga tingkat (three-tier diagnostic test). Pada tes diagnostik empat tingkat. Pada tingkat pertama yaitu pilihan jawaban yang di jawab siswa berbentuk pilihan ganda, pada tingkat kedua yakni tingkat keyakinan jawaban pertanyaan siswa yang dipilihnya, pada tingkat ketiga yakni berbentuk pilihan alasan siswa memilih jawaban pertanyaan yang dipilihnya, serta pada tingkat keempat yakni tingkat keyakinan alasan siswa yang dipilihnya [7].

Terdapat berbagai upaya untuk mereduksi miskonsepsi dan memfasilitasi perubahan konsepsi siswa yang ada yaitu analogi, bentuk pembelajaran yang terdefinisi, pengaplikasian animasi, pembelajaran yang dibantu dengan komputer, belajar dengan berkelompok, demonstrasi, diskusi, serta pemakaian conceptual change text [8].

Pada saat pengembangan software ini menggunakan strategi conceptual change text dikarenakan efektif dalam mengidentifikasi miskonsepsi, meningkatkan pemahaman konsepsi siswa, dan dapat memberikan konsep yang bisa diterima secara ilmiah [9]. Pada conceptual change text yang diperlukan adalah sebagai pereduksi miskonsepsi yang ada pada siswa sebab terdapat penciptaan fase konflik konseptual yang ada di dalamnya. Adanya fase penciptaan konflik tersebut menjadikan skema yang dipunyai siswa mengalami ketidak seimbang (disekuilibrium). Disekuilibrium adalah siswa mulai goyah atau ragu dengan gagasan yang dimiliknya, oleh karena itu siswa diharapkan bisa mengonstruksi gagasan yang tidak sesuai agar bisa memahami konsep dan menerima konsep dengan benar[10]. 
Hal tersebut sesuai dengan keadaaan yang disyaratkan oleh Posner dalam model conceptual change yaitu menciptakan ketidakpuasan terhadap konsep yang dimiliki dan memberi sebuah penjelasan yang lebih jelas, dan masuk akal [11].

Pada strategi CCT (conceptual change text) ini memiliki empat tahapan meliputi (1) menunjukkan konsepsi siswa, (2) konflik konseptual atau konflik kognitif, (3) proses equilibrasi, dan (4) merekontruksi konsep siswa[12].

Berdasarkan uraian yang ada diatas, maka diperlukan adanya software (media) yang cepat dan efektif dalam mendeteksi dan mereduksi miskonsepsi siswa. Oleh karena itu peneliti tertarik untuk melakukan penelitian yang berjudul "Pengembangan Software Anti Mischem Untuk Mereduksi Miskonsepsi Siswa dengan Strategi Conceptual Change Text Pada Materi Asam Basa Kelas XI SMA".

\section{METODE}

Metode yang digunkan dalam mengembangakan software yaitu Research and Development (R\&D) oleh Sugiyono. Metode ini mempunyai sepuluh langkah. Proses yang dilakukan dalam pengembangan terbatas pada langkah uji coba produk yang meliputi : (1) Potensi dan masalah, (2) Pengumpulan data, (3) Desain produk, (4) Validasi desain, (5) Revisi desain, (6) Uji coba produk, (7) Revisi produk, (8) Uji coba pemakaian, (9) Revisi produk, dan (10) Produksi masal. Langkah pengembangan disajikan pada Gambar 1.

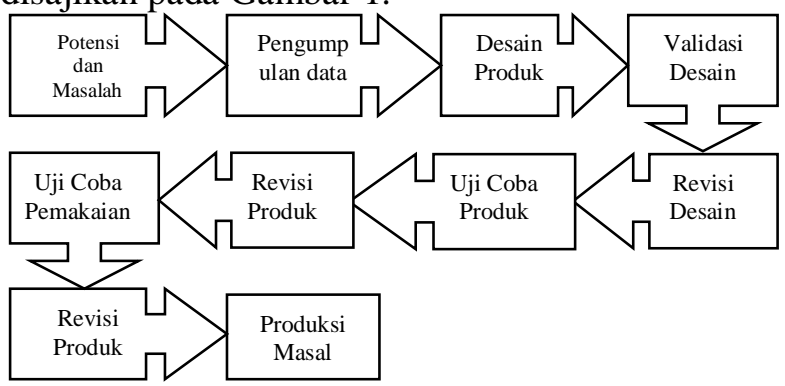

Gambar 1. Langkah-langkah Metode Research and Development (R\&D) [13].

Pada pengembangan software dilaksanakan pada 15 orang siswa SMAN 1 Krembung kelas XI-MIPA 6 yang sudah mendapatkan materi asam basa dan dipilih secara heterogen yang memiliki kriteria miskonsepsi
(M1) sampai miskonsepsi (M7) dan memiliki miskonsepsi tertinggi.

Lembar Instrumen yang digunakan dalam pengembangan meliputi (1) instrumen telaah, (2) instrumen validasi, (3) instrumen angket respon siswa (4) instrumen observasi aktivitas siswa, dan (5) instrumen tes. Metode yang diperlukan dalam menganalisis data meliputi (1) analisis hasil data telaah, (2) analisis hasil data validasi, (3) analisis hasil data angket respon siswa, (4) analisis hasil data observasi aktivitas siswa, dan (5) analisis hasil data pergeseran konsepsi siswa.

Instrumen telaah diperlukan buat mendapatkan saran dan masukan dari dosen kimia, sedangkan pada lembar instrumen validasi dinilai 3 validator meliputi 1 guru kimia SMA dan 2 dosen kimia. Validator dapat memberikan penilaian dengan rentang skor 1-5 dalam lembar instrumen validasi. Kevalidan dapat ditunjukan dengan hasil validasi isi dan hasil validasi konstruk yang dapat dihitung dengan rumus dibawah ini.

$$
\begin{aligned}
& \text { Kevalidan }(\%)=\frac{\Sigma \text { skor keseluruhan }}{\Sigma \text { skor kriteria }} x 100 \% \\
& \text { Persentase hasil kevalidan yang } \\
& \text { didapatkan dari suatu software yang }
\end{aligned}
$$

Tabel 1. Skala Likert

\begin{tabular}{cc}
\hline Persentase (\%) & Kriteria \\
\hline $0-20$ & Tidak Valid \\
$21-40$ & Kurang Valid \\
$50-60$ & Cukup Valid \\
$61-80$ & Valid \\
$81-100$ & Sangat Valid \\
\hline
\end{tabular}

Berdasarkan pada Tabel 1 tertera kriteria software dinyatakan valid bilamana mendapatkan $\geq 61 \%$. Kepraktisan dapat ditunjukan dengan hasil angket respon siswa serta didukung dengan hasil observasi aktivitas siswa. Perolehan keduanya dapat dinilai menggunakan skala Guttman yang disajikan pada Tabel 2, dengan rumus sebagai berikut.

$$
\mathrm{P}=\frac{\mathrm{F}}{\mathrm{N}} \times 100 \%
$$

$\mathrm{F}=$ Banyak siswa menjawab "Ya" atau "Tidak"

$\mathrm{N}=$ Banyak siswa yang digunakan dalam uji coba 
Tabel 2. Skala Guttman.

\begin{tabular}{cccc}
\hline \multirow{2}{*}{ Pernyataan } & \multicolumn{3}{c}{ Nilai/Skor } \\
\cline { 2 - 3 } & Ya & Tidak \\
\hline Positif & 1 & 0 & \\
Negatif & 0 & 1 & {$[14]$}
\end{tabular}

Keefektifan dapat ditunjukan dengan hasil data output pergeseran konsepsi siswa yang awalnya mengalami miskonsepsi menjadi paham konsep. Didalam software terdapat tes awal (pretest) dan tes akhir (posttest) yang menggunakan pola four-tier diagnostic test. Dalam metode tersebut mempunyai 4 tingkatan. Tingkat pertama pilihan jawaban berbentuk pilihan ganda, Tingkat kedua berupa keyakinan dari jawaban yang dipilih, Tingkat ketiga berbentuk alasan dari jawaban yang dipilh, Tingkat keempat berupa keyakinan dari alasan yang dipilihnya [7]. Pada metode four-tier diagnostic test ini dapat digolongkaan siswa kedalam kelasifikasi pemahaman konsep siswa yang disajikan dalam Tabel 3.

Tabel 3. Kelasifikasi Pemahaman Konsep Siswa

\begin{tabular}{ccccl}
\hline Tingkat Pertama & Tingkat Kedua & Tingkat Ketiga & Tingkat Keempat & Kriteria \\
\hline Benar & Yakin & Benar & Yakin & Paham Konsep (PK) \\
Benar & Tidak Yakin & Benar & Tidak Yakin & Tidak Paham Konsep (TPK) \\
Benar & Yakin & Benar & Tidak Yakin & Tidak Paham Konsep (TPK) \\
Benar & Tidak Yakin & Benar & Yakin & Tidak Paham Konsep (TPK) \\
Benar & Tidak Yakin & Salah & Tidak Yakin & Tidak Paham Konsep (TPK) \\
Salah & Tidak Yakin & Benar & Tidak Yakin & Tidak Paham Konsep (TPK) \\
Salah & Tidak Yakin & Salah & Tidak Yakin & Tidak Paham Konsep (TPK) \\
Benar & Yakin & Salah & Tidak Yakin & Tidak Paham Konsep (TPK) \\
Salah & Tidak Yakin & Benar & Yakin & Tidak Paham Konsep (TPK) \\
Benar & Tidak Yakin & Salah & Yakin & Miskonsepsi 1 (M1) \\
Benar & Yakin & Salah & Yakin & Miskonsepsi 2 (M2) \\
Salah & Yakin & Benar & Tidak Yakin & Miskonsepsi 3 (M3) \\
Salah & Yakin & Benar & Yakin & Miskonsepsi 4 (M4) \\
Salah & Yakin & Salah & Tidak Yakin & Miskonsepsi 5 (M5) \\
Salah & Tidak Yakin & Salah & Yakin & Miskonsepsi 6 (M6) \\
Salah & Yakin & Salah & Yakin & Miskonsepsi 7 (M7) \\
\hline
\end{tabular}

Persentase pergeseran konsepsi siswa dari miskonsepsi (MK) menjadi paham konsep (PK) dapat dihitung dengan rumus sebagai berikut :

Pergeseran miskonsepsi $(\%)=\frac{\Sigma M K-P K}{\Sigma M K a w a l ~} x 100 \%$

$\boldsymbol{\Sigma}$ MK-PK = Jumlah pergeseran konsep dari miskonsepsi ke paham konsep

$\boldsymbol{\Sigma}$ MK awal = Jumlah miskonsepsi awal sebelum bergeser.

Hasil persentase pergeseran miskonsepsi yang diperoleh diinterpretasikan kedalam skor skala Likert [14]. Software dapat dibilang efektif jika persentase yang didapatkan $\geq 61 \%$.

\section{HASIL DAN PEMBAHASAN}

Hasil analisis dan pembahasan pengembangan software diuraikan sebagai berikut:

\section{a. Potensi dan Masalah}

Pada tahap potensi dan masalah ini dilakukan dengan cara studi lapangan di SMA Negeri 1 Krembung pada kelas XI-MIPA. Pada saat studi lapangan, peneliti menemukan kondisi dimana interaksi antara guru dan siswa dapat terjalin baik saat pembelajaran. Namun masalahnya pada hasil wawancara yang dilakukan terhadap guru diperoleh bahwa guru kesulitan menentukan solusi yang dapat digunakan untuk menjelaskan materi asam basa kepada siswa yang mengalami miskonsepsi dan siswa yang kesulitan dalam memahami konsep tersebut.

Pada saat pembelajaran siswa hanya menggunakan buku paket dan LKS. Hal tersebut memungkinkan menjadi masalah dimana siswa kurang tertarik untuk membaca atau belajar sehingga siswa tidak dapat memahami konsep dengan baik dan benar. Dalam hal ini, media 
pembelajaran sangat dibutuhkan dalam proses pembelajaran dikelas dan dapat memberikan suasana baru dalam belajar sehingga siswa lebih tertarik dan lebih bersemangat dalam belajar.

\section{b. Pengumpulan Data}

Pada tahap pengumpulan data ini digunakan sebagai bahan dalam merencanakan software anti mischem yang akan dikembangkan untuk mereduksi miskonsepsi siswa pada materi asam basa dengan strategi conceptual change text. Tahap ini dilakukan melalui studi literatur tentang penelitian terdahulu mengenai miskonsepsi yang terjadi pada materi asam basa. Kemudian selanjutnya dilakukan pra penelitian di sekolah SMAN 1 Krembung pada tahun ajaran semester genap 2019/2020 dikelas XI-MIPA 6 maka diketahui bahwa persentase rata-rata analisis miskonsepsi sebanyak 49,10\% siswa mengalami miskonsepsi pada teori asam basa Arrhenius, 47,32\% siswa mengalami miskonsepsi pada teori asam basa Bronsted lowry, 60,71\% siswa mengalami miskonsepsi pada teori asam basa Lewis, dan 61,60\% siswa mengalami miskonsepsi pada kekuatan asam.

Dari data - data tersebut dapat dibuat rancangan produk untuk mengatasi masalah miskonsepsi yang terjadi pada siswa.

\section{c. Desain Produk}

Pada tahap desain produk peneliti merancang software yang dapat digunakan untuk mereduksi miskonsepsi siswa dengan strategi conceptual change text pada materi asam basa. Adapun bagian-bagian hasil desain produk dijelaskan sebagai berikut :

\section{Halaman Login}

Halaman Login merupakan menu akses masuk ke software. Pada halaman login, terdapat kolom NIS dan kode paket yang di dapatkan dari guru atau admin. Tampilan halaman login dapat dilihat pada Gambar 2.

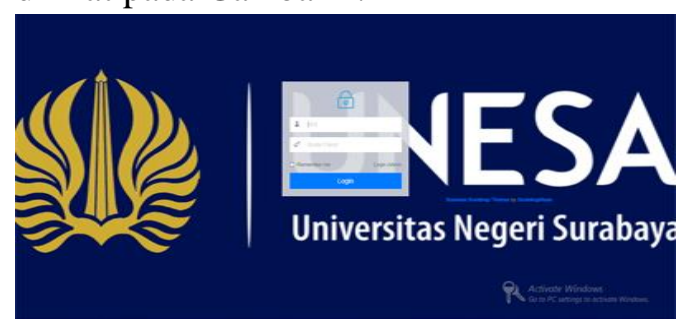

Gambar 2. Halaman login.

\section{Halaman Menu Utama}

Pada halaman menu utama terdapat nama siswa, NIS siswa, kode paket,pilhan konsep yang akan dikerjakan, petunjuk, dan logout. Sebelum mengerjakan terlebih dahulu siswa membaca petunjuk pada menu petunjuk. Tampilan halaman menu utama dapat disajiakan pada Gambar 3.

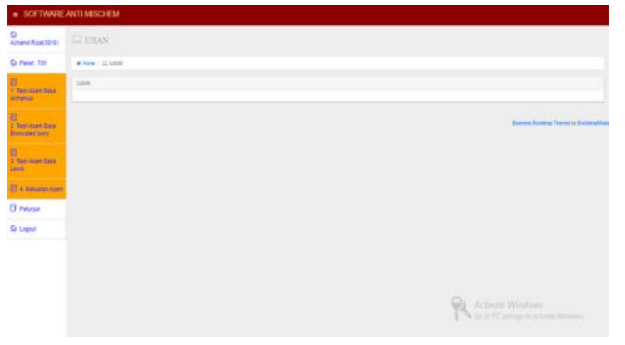

Gambar 3. Halaman Menu Utama.

3. Halaman Petunjuk

Pada halaman petunjuk terdapat cara mengoperasikan software yang dibuat dengan adobe flash CS6. Tampilan halaman petunjuk dapat dilihat pada Gambar 4.

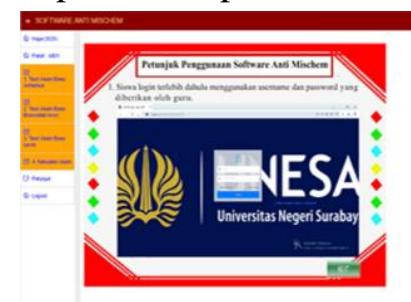

Gambar 4. Halaman Petunjuk.

\section{Soal Pretest}

Setelah memilih salah satu konsep, siswa diberikan beberapa soal pretest untuk dikerjakan. Soal berupa instrumen model four-tier test untuk mengetahui konsepsi yang ada pada siswa. Instrumen model four-tier test dipilih karena lebih sensitif dalam memetakan keyakinan atau percaya diri siswa terhadap jawaban dan alasan jawaban [15]. Jika siswa terdeteksi miskonsepsi atau tidak paham konsep diberitahu dan diarahkan untuk menekan tombol HELP/MATERI untuk memperbaiki konsepsi yang dimilikinya. Tampilan soal pretest dapat dilihat pada Gambar 5.

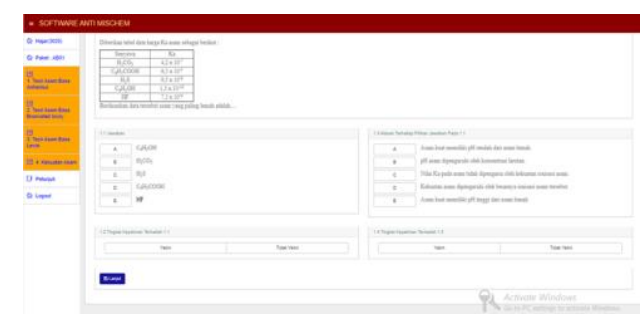

Gambar 5. Tampilan soal pretest. 


\section{Conceptual Change Text}

Pada bagian pereduksi konsep siswa diberikan strategi conceptual change text yang terdiri dari empat tahap meliputi : (1) menunjukakan konsepsi siswa yang ada pada CCT 1 dalam software, (2) membuat konflik kognitif yang ada pada CCT 2 dalam software, (3) proses equilibrasi yang ada pada CCT 3 dalam software, (4) rekontruksi konsep yang ada pada CCT 4 dalam software[11]. Tampilan conceptual change text (CCT) disajikan pada Gambar 6.

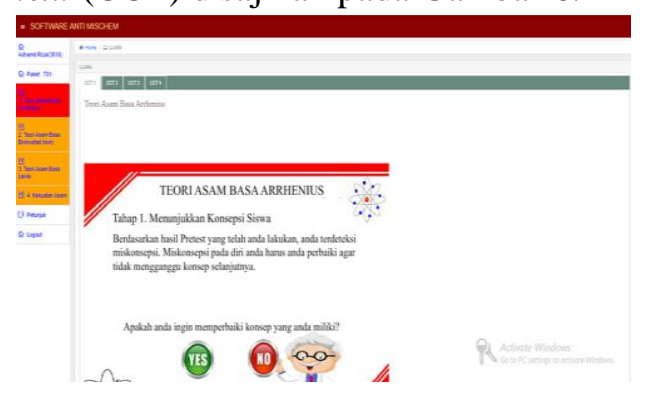

Gambar 6. Tampilan Conceptual Change Text.

\section{d. Validasi Desain}

$\begin{array}{ccr}\text { Validasi desain diperlukan untuk } \\ \text { mendapatkan kelayakan } & \text { software yang }\end{array}$ dikembangkan dan penilaian dari tiga validator yaitu guru kimia SMA dan dua dosen kimia. Validasi yang dinilai adalah validasi isi dan validasi konstruk. Suatu instrumen dapat dinyatakan layak jika masing-masing kriteria mempreoleh persentase $\geq 61 \%$. Adapun rincian hasil validasi isi software dapat dilihat pada Tabel 4 dan rincian data hasil validasi konstruk dapat dilahat pada Tabel 5 .

Tabel 4. Data Hasil Validasi Isi

\begin{tabular}{|c|c|c|}
\hline Aspek yang dinilai & Persentase (\%) & Kategori \\
\hline Kesesuain Materi & 85 & Sangat valid \\
\hline Kes & 85 & \\
\hline $\begin{array}{l}\text { Kesesuaian } \\
\text { Bahasa dan } \\
\text { Tampilan }\end{array}$ & 83,33 & \\
\hline Rata-rata & 84,63 & Sangat valid \\
\hline
\end{tabular}

Berdasarkan Tabel 4 diatas mempunyai tiga aspek meliputi aspek pertama kesesuaian materi dalam software mendapat $85 \%$. Hal ini menunjukan materi yang digunakan sudah sesuai, baik dari simbol, angka dan rumus senyawa dan nama senyawanya sudah tepat sehingga tidak menimbulkan terjadinya miskonsepsi [16].

Pada aspek kedua kesesuaian soal dalam software mendapat persentase $85,56 \%$. Hal ini butir soal yang disajikan pada software merupakan butir soal yang dapat mewakili materi asam basa, dan sudah dapat digunakan untuk mendeteksi konsepsi siswa, serta sudah sesuai dengan KD yang ada pada kemendikbud kurikulum 2013 revisi [16].

Sedangkan pada aspek ketiga kesesuaian bahasa dan tampilan yang digunakan dalam software mendapat persentase sebesar $83,33 \%$. Hal ini bahasa yang digunakan sudah baik dan benar serta tidak menimbulkan penafsiran ganda. serta perlu dipertimbangkan karena salah satu hal yang menyebabkan terjadinya miskonsepsi oleh karena itu siswa akan kesulitan dalam memahami bahasa selama pembelajaran [17]. Selain itu tampilan yang ada pada software sudah baik dan tidak menganggu pengelihatan bacaan yang ada.

Secara keseluruhan persentase rata-rata hasil validasi isi mendapat $84,63 \%$ dan termasuk kriteria sangat valid

Tabel 5. Hasil Data Validasi Konstruk

\begin{tabular}{lcc}
\hline Aspek yang dinilai & Persentase (\%) & Kategori \\
\hline Kesesuaian soal & 86,67 & Sangat valid \\
Kesesuaian video & 77,78 & Valid \\
Rata-rata & 82,22 & Sangat valid \\
\hline
\end{tabular}

Berdasarkan Tabel 5 diatas, mempunyai dua aspek. Aspek pertama kesesuaian soal dalam mereduksi miskonsepsi pada software mendapatkan persentase $86,67 \%$. Pada aspek kedua yaitu kesesuaian video yang digunakan dalam software mendapat rata-rata persentase $77,78 \%$. Hal ini video yang digunakan tidak mengandung SARA sehingga dapat diterapakan untuk berbagai kalangan dengan sarana memadai [18].

Secara keseluruhan persentase hasil validasi konstruk memperoleh $82,22 \%$ dan termasuk kriteria sangat valid.

\section{e. Revisi Desain}

Pada tahap revisi desain software berdasarkan saran dan komentar yang diberikan oleh validator. Berikut beberapa saran :

a) Mengkunci tombol lanjut pada soal sebelum selesai menjawab semua.

b) Memperbaiki kualitas video yang ada dalam flash.

c) Memperbaiki tulisan senyawa yang ada pada video. 


\section{f. Uji Coba Produk}

Uji coba produk dilakukan pada 15 siswa yang bertujuan untuk mengetahu kepraktisan dan keefektifan software. Kepraktisan software ditinjau dari hasil angket respon siswa yang diperoleh dari lembar angket respon siswa yang dibagikan pada 15 siswa yang sudah melakukan uji coba software. Adapun rincian hasil data angket respon siswa yang ditunjukkan pada Tabel 6.

Tabel 6. Hasil Data Angket Respon Siswa

\begin{tabular}{|c|c|c|}
\hline \multicolumn{2}{|c|}{ Aspek yang dinilai Persentase (\%) } & Kriteria \\
\hline Mengidentifikasi & 83,33 & Sangat \\
\hline $\begin{array}{ll}\text { software } & \text { dapat } \\
\text { menarik rasa } & \text { ingin } \\
\text { tahu siswa } & \end{array}$ & & Praktis \\
\hline $\begin{array}{l}\text { Mengetahui } \\
\text { kejelasan bahasa } \\
\text { dalam software }\end{array}$ & 73,33 & Praktis \\
\hline $\begin{array}{l}\text { Mengetahui tingkat } \\
\text { kemudahan dalam } \\
\text { menggunakan } \\
\text { software }\end{array}$ & 83,33 & $\begin{array}{l}\text { Sangat } \\
\text { Praktis }\end{array}$ \\
\hline $\begin{array}{l}\text { Mengetahui fase } \\
\text { semangat belajar } \\
\text { siswa pada saat } \\
\text { penggunan software }\end{array}$ & 73,33 & Praktis \\
\hline Rata-rata & 78,33 & Praktis \\
\hline
\end{tabular}

Berdasarkan Tabel 6 diatas dapat diketahui hasil persentase respon siswa selama melakukan uji coba software. Penilaian respon siswa tersebut memuat empat aspek yang dinilai. Pada aspek pertama yaitu software dapat menarik rasa ingin tahu siswa mendapatkan persentase 83,33\%.Pada aspek kedua yaitu kejelasan bahasa dalam software diperoleh persentase 73,33\%. Pada aspek ketiga yaitu tingkat kemudahan dalam menggunakan software mendapat persentase sebesar $83,33 \%$.Sedangkan pada aspek keempat yaitu fase semangat belajar siswa pada saat penggunan software diperoleh persentase 73,33\%. Software anti mischem dapat dinyatakan praktis jika mendapat persentase $\geq 61 \%$. Secaraa kesluruhan mendapat rata-rata persentase 78,33\% sehingga dapat dikategorikan baik atau praktis.

Selain itu ada hasil observasi aktivitas siswa didapatkan dari aktivitas siswa selama menggunakan software dan diperlukan buat mendukung dari data hasil angket respon siswa,serta buat mengerti kepraktisan dari software yang dikembangkan. Adapun rincian dari data hasil observasi aktivitas siswa yang dapat dilihat pada Tabel 7.

Tabel 7. Hasil Observasi Aktivitas Siswa

\begin{tabular}{|c|c|c|}
\hline Aspek yang diamati & Persentase (\%) & Kategori \\
\hline $\begin{array}{lr}\text { Siswa } & \text { dapat } \\
\text { mengopersikan } \\
\text { software dengan } \\
\text { baik } \quad \text { (tidak } \\
\text { mengajukan } & \\
\text { pertanyaan) } & \end{array}$ & 86,67 & $\begin{array}{l}\text { Sangat } \\
\text { Praktis }\end{array}$ \\
\hline $\begin{array}{l}\text { Siswa dapat } \\
\text { mengopersikan } \\
\text { tombol - tombol } \\
\text { dalam software } \\
\text { dengan baik (tidak } \\
\text { mengutarakan } \\
\text { pertanyaan) }\end{array}$ & 86,67 & $\begin{array}{l}\text { Sangat } \\
\text { Praktis }\end{array}$ \\
\hline $\begin{array}{l}\text { Siswa tidak keluar } \\
\text { kelas kelas saat } \\
\text { melakuakan uji coba } \\
\text { software tanpa } \\
\text { alasan }\end{array}$ & 100 & $\begin{array}{l}\text { Sangat } \\
\text { Praktis }\end{array}$ \\
\hline \begin{tabular}{lr}
\multicolumn{2}{l}{ Siswa mengutarakan } \\
pertanyaan & pada \\
tampilan & tertentu \\
(jika ya, & tuliskan \\
bagian & yang \\
ditanyakan) &
\end{tabular} & 80 & Praktis \\
\hline $\begin{array}{lr}\text { Siswa mengajuan } \\
\text { pertanyaan tentang } \\
\text { cara penggunan } \\
\text { software } r \text { karena } \\
\text { siswa } \quad \text { kurang } \\
\text { memahami fungsi } \\
\text { setiap tombol yang } \\
\text { terdapat } \\
\text { software. }\end{array}$ & 80 & Praktis \\
\hline $\begin{array}{l}\text { Siswa membaca } \\
\text { dengan seksama } \\
\text { conceptual change } \\
\text { text yang disajikan }\end{array}$ & 80 & Praktis \\
\hline $\begin{array}{lr}\text { Siswa } & \text { termotivasi } \\
\text { untuk mempelajari } \\
\text { setiap tampilan pada } \\
\text { software (hal ini } \\
\text { dilihat } & \text { dari } \\
\text { antusiasme } & \text { siswa } \\
\text { yaitu } & \text { dalam } \\
\text { memusatkan } & \\
\begin{array}{l}\text { perhatiannya } \\
\text { software) }\end{array} & \\
\text { pada }\end{array}$ & 86,67 & $\begin{array}{l}\text { Sangat } \\
\text { Praktis }\end{array}$ \\
\hline Rata-rata & 85,83 & $\begin{array}{l}\text { Sangat } \\
\text { Praktis }\end{array}$ \\
\hline
\end{tabular}


Berdasarkan pada Tabel 7 diatas bisa diketahui persentase hasil aktivitas siswa selama menggunakan software. Penilaian observasi aktivitas siswa tersebut memuat tujuh aspek yang dinilai. Berdasarkan hasil observasi aktivitas siswa software anti mischem dinyatakan praktis apabila persentase $\geq 61 \%$.

Secara kesluruhan diperoleh rata-rata persentase sebesar $85,83 \%$ sehingga dapat dikategorikan sangat praktis. Hal ini membuktikan bahwa software yang dikembangkan dapat dikatakan praktis.

Keefektifan ditunjukan dengan output software anti mischem. Output dari software anti mischem yaitu hasil data pergeseran konsepsi siswa yang diketahuinya sesudah mengerjakan soal pretest, membaca conceptual change text (CCT), dan mengerjakan soal posttest. Hasil pergeseran konsepsi siswa pada teori asam basa Arrhenius, Bronsted Lowry, dan Lewis disajikan pada Tabel 8 dan hasil pergeseran konsepsi kekuatan asam dapat dilihat pada Tabel 9 .

Tabel 8. Hasil Pergeseran Konsepsi Pada Teori Asam Basa Arrhenius, Bronsted Lowry, dan Lewis.

\begin{tabular}{|c|c|c|c|c|c|c|c|c|c|c|c|c|c|c|c|}
\hline \multirow{2}{*}{$\begin{array}{c}\text { Hasil } \\
\text { Pergeseran } \\
\text { Konsepsi }\end{array}$} & \multicolumn{4}{|c|}{ Arrhenius } & \multirow[b]{2}{*}{ Total } & \multicolumn{4}{|c|}{ Bronsted Lowry } & \multirow[b]{2}{*}{ Total } & \multicolumn{4}{|c|}{ Lewis } & \multirow[b]{2}{*}{ Total } \\
\hline & 1 & 2 & 3 & 4 & & 1 & 2 & 3 & 4 & & 1 & 2 & 3 & 4 & \\
\hline $\mathrm{PK}-\mathrm{PK}$ & 8 & 5 & 2 & 4 & 19 & 2 & 2 & 9 & 3 & 16 & 13 & 1 & 3 & 3 & 20 \\
\hline PK - TPK & 0 & 0 & 0 & 0 & 0 & 0 & 0 & 0 & 0 & 0 & 0 & 0 & 0 & 0 & 0 \\
\hline $\mathrm{PK}-\mathrm{MK}$ & 0 & 0 & 0 & 0 & 0 & 0 & 0 & 0 & 0 & 0 & 0 & 0 & 0 & 0 & 0 \\
\hline $\mathrm{MK}-\mathrm{PK}$ & 7 & 6 & 8 & 9 & 30 & 10 & 10 & 5 & 10 & 35 & 2 & 9 & 8 & 10 & 29 \\
\hline $\mathrm{MK}-\mathrm{MK}$ & 0 & 1 & 1 & 2 & 4 & 0 & 1 & 1 & 2 & 4 & 0 & 5 & 3 & 2 & 10 \\
\hline MK -TPK & 0 & 0 & 0 & 0 & 0 & 1 & 0 & 0 & 0 & 1 & 0 & 0 & 0 & 0 & 0 \\
\hline TPK - PK & 0 & 2 & 3 & 0 & 5 & 2 & 2 & 0 & 0 & 4 & 0 & 0 & 1 & 0 & 1 \\
\hline TPK - MK & 0 & 1 & 1 & 0 & 2 & 0 & 0 & 0 & 0 & 0 & 0 & 0 & 0 & 0 & 0 \\
\hline TPK - TPK & 0 & 0 & 0 & 0 & 0 & 0 & 0 & 0 & 0 & 0 & 0 & 0 & 0 & 0 & 0 \\
\hline \multicolumn{6}{|c|}{$\begin{array}{l}\mathrm{P}(\%)=\frac{\sum \mathrm{MK}-\mathrm{PK}}{\sum \mathrm{MKawal}} \times 100 \% \\
\mathrm{P}(\%)=\frac{30}{34} \mathrm{x} 100 \%=88,23 \%\end{array}$} & \multicolumn{5}{|c|}{$\begin{array}{l}\mathrm{P}(\%)=\frac{\sum \mathrm{MK}-\mathrm{PK}}{\sum \mathrm{MKawal}} \times 100 \% \\
\mathrm{P}(\%)=\frac{35}{40} \times 100=87,5 \%\end{array}$} & \multicolumn{5}{|c|}{$\begin{array}{l}\mathrm{P}(\%)=\frac{\sum \mathrm{MK}-\mathrm{PK}}{\sum \mathrm{MKawal}} \times 100 \% \\
\mathrm{P}(\%)=\frac{29}{39} \times 100=74,36 \%\end{array}$} \\
\hline
\end{tabular}

Keterangan :

PK $=$ Paham Konsep $\quad$ MK $=$ Miskonsepsi

TPK $=$ Tidak Paham Konsep

Berdasarkan Tabel 8 diatas ditunjukan hasil pergeseran konsepsi asam basa Arrhenius dari PK - PK terdapat 19. Hal ini konsep yang dimiliki siswa sudah benar. MK - PK ada 30 . Hal ini membuktikan bahwa siswa sudah melewati tahap operasional formal (berpikir abstrak) sesuai dengan teori Piaget [21]. Selain itu, siswa mampu menerima dan memahami konsep yang benar terutama pada konsep abstrak [22]. Pada MK MK hanya ada 4. Hal ini terjadi karena siswa mengalami kesulitan atau kurang mampu memahami dan menerima konsep yang benar terutama pada konsep abstrak [22]. Hal ini sesuai dengan teori perkembangan kognitif dari Piaget mengenai tahap operasioanl formal. Saat siswa tidak mampu melewati tahap operasional formal (berpikir abstrak), maka siswa tersebut akan kesulitan menerima dan memahami materi sehingga tetap mengalami miskonsepsi [21]. TPK - PK ada sebanyak 5 jawaban siswa. Hal ini terjadi karena siswa telah melewati tahap operasional formal (berpikir abstrak) sesuai dengan teori Piaget [21]. Sehingga siswa mampu menerima dan memahami konsep yang benar terutama pada konsep abstrak[22]. TPK - MK ada 2 jawaban siswa. Hal ini terjadi karena siswa mengalami kesulitan atau kurang mampu memahami dan menerima konsep yang benar[22]. Siswa yang mengalami Miskonsepsi awal (MK awal) terdapat 34 jawaban. Sehingga hasil persentase pergeseran konsepsi pada teori asam basa arrhenius $88,23 \%$.

Hasil data pergeseran konsepsi asam basa Bronsted Lowry pada Tabel 8 dapat diketahui dari PK - PK ada 16. MK - PK ada 35. MK - MK hanya ada 4. MK - TPK ada 1. TPK - PK terdapat 4. Pada MK awal terdapat 40. Sehingga 
persentase pergeseran konsepsi asam basa Brosnted Lowry didapatkan 87,5\%.

Sedangkan hasil pergeseran konsepsi asam basa lewis pada Tabel 8 dari PK - PK ada 20. MK - PK ada 29. MK - MK hanya ada 10. TPK - PK ada 1. Pada siswa yang mengalami MK awal terdapat 39. Secara keseluruhan hasil persentase pergeseran konsepsi pada teori asam basa Lewis didapatkan $74,36 \%$.

Tabel 9. Hasil Pergeseran Konsepsi Kekuatan Asam.

\begin{tabular}{|c|c|c|c|c|c|}
\hline \multirow{2}{*}{$\begin{array}{c}\text { Hasil } \\
\text { Pergeseran } \\
\text { Konsepsi }\end{array}$} & \multicolumn{4}{|c|}{ Kekuatan Asam } & \multirow[b]{2}{*}{ Total } \\
\hline & 1 & 2 & 3 & 4 & \\
\hline $\mathrm{PK}-\mathrm{PK}$ & 1 & 4 & 0 & 0 & 5 \\
\hline PK - TPK & 0 & 0 & 0 & 0 & 0 \\
\hline $\mathrm{PK}-\mathrm{MK}$ & 0 & 0 & 0 & 0 & 0 \\
\hline $\mathrm{MK}-\mathrm{PK}$ & 12 & 8 & 13 & 13 & 46 \\
\hline $\mathrm{MK}-\mathrm{MK}$ & 1 & 1 & 1 & 1 & 4 \\
\hline MK -TPK & 0 & 0 & 0 & 0 & 0 \\
\hline TPK - PK & 1 & 2 & 1 & 0 & 4 \\
\hline TPK - MK & 0 & 0 & 0 & 1 & 1 \\
\hline TPK - TPK & 0 & 0 & 0 & 0 & 0 \\
\hline \multicolumn{6}{|c|}{$\begin{aligned} P(\%) & =\frac{\sum M K-P K}{\sum M K a w a l} \times 100 \% \\
P(\%) & =\frac{46}{50} x 100 \%=92 \%\end{aligned}$} \\
\hline
\end{tabular}

Berdasarkan Tabel 9 diatas ditujukkan hasil pergeseran konsepsi kekuatan asam dari PK - PK terdapat 5 jawaban. MK - PK ada sebanyak 46. MK - MK ada sebanyak 4. TPK - PK hanya ada 4. TPK - MK hanya ada 1. Siswa yang mengalami MK awal ada 50. Sehingga persentase pergeseran konsepsi yang didapatkan $92 \%$.

\section{PENUTUP}

\section{Simpulan dan Saran}

Dari hasil penelitian dapat disimpulkan bahwa software yang dikembangkan bisa dikatakan baik atau layak dengan perincian kriteria sebagai berikut :

1. Validitas dapat dinyatakan valid dengan ditunjukkannya perolehan dari data hasil validasi isi mendapat $84,63 \%$ dengan kategori sangat valid dan perolehan dari persentase hasil validasi konstruk didapatkan rata-rata $82,22 \%$ dan termasuk kategori sangat valid.

2. Kepraktisan dapat dinyatakan praktis dengan ditunjukkan perolehan dari persentase hasil data angket respon siswa sebesar 78,33\% dengan kategori praktis dan perolehan dari persentase hasil data observasi aktivitas siswa didapatkan rata-rata $85,83 \%$ dengan kategori sangat praktis dan digunakan sebagai data pendukung angket respon siswa.

3. Keefektifan dapat dinyatakan efektif dengan ditunjukkannya dari persentase rata-rata pergeseran konsepsi siswa yang awalnya miskonsepsi menjadi paham konsep sebesar $85,52 \%$ dan termasuk kategori sangat efektif.

\section{Saran}

Berdasarkan hasil penelitian yang sudah dilakukan, software anti mischem sudah memenuhi kriteria kevalidan,kepraktisan,dan keefektifan. Beberapa saran diperlukan untuk penyempurnaan pada penelitian selanjutnya yaitu:

1. Penelitian tersebut hanya dilakuakan sampai pada uji coba terbatas untuk mendapatkan informasi yang lebih, sehingga diperlukan penelitian lebih lanjut agar dapat digunakan oleh siswa dengan jumlah yang lebih banyak.

2. Software anti mischem yang dikembangkan dapat digunakan untuk mereduksi miskonsepsi siswa dan dapat diterapkan pada matari lain sehingga semakin dapat dirasakan manfaatnya.

3. Penggunaan software anti mischem dengan memakai LAN sendiri (Tethering Hotspot) terbatas pada beberapa laptop sehingga dibutuhkan WiFi untuk menjangkau dalam jumlah yang lebih banyak dan dalam waktu yang bersamaan.

\section{DAFTAR PUSTAKA}

1. Permendikbud. 2013. Lampiran Peraturan Menteri Pendidikan dan Kebudayaan Republik Indonesia Nomor 69 Tahun 2013 tentang Kerangka Dasar dan Struktur Kurikulum Sekolah Menengah Atas/ Madrasah Aliyah. Jakarta: Kementerian Pendidikan dan Kebudayaan Republik Indonesia .

2. Saputri, C. Y., \& Sukarmin. 2019. Pengemabagan Software Anti Miskim untuk Mereduksi Miskonsepsi Melalui Strategi Conceptual Change Text Siswa Kelas XI pada Materi Asam Basa. Unesa Journal of Chemical Education, Vol.8, No.3, pp. 463-468.

3. Mulyo, S. A., \& Sukarmin. 2019. Pengembangan Software Anti Mischem untuk Mereduksi Miskonsepsi Siswa dengan Strategi 
Conceptual Change Text pada Materi Hidrolisis Garam Kelas XI SMA. Unesa Journal of Chemical Education, Vol. 8, No. 1, pp, 32-38.

4. Musdalifa, R., \& Sukarmin. 2018. Pengembangan Software Anti Chemmisco untuk Mereduksi Miskonsepi Siswa pada Materi Laju Reaksi melalui Strategi Conceptual Change Text . Prosiding Seminar Nasional Kimia (hal. 76-86). Surabaya: Jurusan Kimia FMIPA Universitas Negeri Surabaya.

5. Ibrahim, M. 2012. Konsep, Miskonsepsi dan Cara Pembelajaran. Surabaya: Unesa University Press.

6. Rositasari, Dessy, Saridewi, Nanda, \& Agung, S. 2014. Pengembangan Tes Diagnostik TwoTier untuk Mendeteksi Miskonsepsi Siswa SMA pada Topik Asam-Basa. Journal Chemistry Education, Vol. 6, No.02, pp. 173176.

7. Fariyani, Q., Rusilowati, A., \& Sugianto. 2015. Pengembangan Four-Tier Diagnostic Test untuk Mengungkap Miskonsepsi Fisika Siswa SMA Kelas X. Journal of Innovative Science Education, Vol. 4, No. 2, pp. 41 - 49.

8. Guzzetti, B. J. 2000. Learning CounterIntuitive Science Concepts: What Have We Learned From Over A Decade of Research. Reading and Writing Quarterly, Vol. 16, No. 2, pp. 89-98.

9. Sari, B. P., Feranie, S., \& Winarno, N. 2017. The Use of Conceptual Change Text toward Students' Argumentation Skills in Learning Sound. International Conference on Mathematics and Science Education (ICMScE) (hal. 1-5). Bandung: IOP Publishing.

10.Effendy. 2002. Upaya untuk Mengatasi Kesalahan Konsep dalam Pengajaran dengan Menggunakan Strategi Konflik Kognitif.Media
Komunikasi kimia, Vol. 2, No. 6, pp. 1-19.

11.Ozkan, G., \& Selcuk, G.S. 2015. Effect of Technology Enhanced Conceptual Change Text on Students's Understanding of Buoyant Force. Universal Journal of Educational Research, Vol. 3, No 12, pp. 981-988.

12.Sendur, G., \& Toprak, M. 2013. The Role of Conceptual Change Texts to Improve Students' Understanding of Alkenes. Chemistry Education Research and Practice, Vol. 14, No. 1, pp. 431 - 449.

13.Sugiyono. 2017. Metode Penelitian Kuantitatif, Kualitatif dan $R \& D$. Bandung: Alfabeta.

14.Riduwan. 2015. Skala Pengukuran Variabel variabel Penelitian. Bandung: Alfabeta.

15.Gurel, D. E. Eryilmaz, A. \& McDermott, L.C. 2015. A Review and Comparison of Diagnostic Instruments to Identify Student's Misconceptions in Science. Eurasia Journal of Mathematics, Science \& Technology Education, Vol.11, No 15, pp. 989-1008.

16.Alwi, S. 2017. Problematika Guru dalam Pengembangan Media Pembelajaran. Itqan, Vol 8, No 2, pp. 145-167.

17.Nurhidayatullah, N. \& Prodjosantoso, A.K. 2018. Miskonsepsi Materi Larutan Penyangga. Jurnal Inovasi Pendidikan IPA, Vol 4, No 1, pp. 41-51.

18.Munadlir, A. 2016. Strategi Sekolah dalam Pendidikan Multicultural . Jurnal Pendidikan Sekolah Dasar, Vol. 2, No 2, pp. 114-130.

19.Slavin, R.E. 2011. Psikologi Pendidikan :Teori dan Praktik. Jakarta: indek.

20.Asy'ari, M. 2018. Identifikasi Miskonsepsi Mahasiswa Pendidikan Fisika pada Materi Rangkaian Listrik . Jurnal Ilmiah Pendidikan Fisika, Vol. 4, No 2, pp. 98-105. 